\title{
In vitro activity of telithromycin against Haemophilus influenzae at epithelial lining fluid concentrations Elena De Vecchi ${ }^{1}$, Lucia Nicola ${ }^{1}$, Monica Larosa ${ }^{2}$ and Lorenzo Drago*1
}

\author{
Address: 'Laboratory of Clinical Microbiology, Department of Preclinical Sciences LITA Vialba, University of Milan, Via GB Grassi 74, 20159 Milan \\ Italy and ${ }^{2}$ Medical Affairs \& Scientific Relations, sanofi-aventis, v.le L. Bodio 37/b - Milano Milan, Italy \\ Email: Elena De Vecchi - elena.devecchi@unimi.it; Lucia Nicola - microbio@unimi.it; Monica Larosa - Monica.Larosa@sanofi-aventis.com; \\ Lorenzo Drago* - lorenzo.drago@unimi.it \\ * Corresponding author
}

Published: 29 January 2008

BMC Microbiology 2008, 8:23 doi:10.1 |86/147|-2/80-8-23
Received: 13 July 2007

Accepted: 29 January 2008

This article is available from: http://www.biomedcentral.com/I47I-2I80/8/23

(c) 2008 De Vecchi et al; licensee BioMed Central Ltd.

This is an Open Access article distributed under the terms of the Creative Commons Attribution License (http://creativecommons.org/licenses/by/2.0), which permits unrestricted use, distribution, and reproduction in any medium, provided the original work is properly cited.

\begin{abstract}
Background: Haemophilus influenzae is one of the main aetiological agents of community-acquired respiratory tract infections. The primary aim of this study was to evaluate the antibacterial activity of telithromycin against $H$. influenzae clinical isolates showing different pattern of resistance in comparison with azithromycin and clarithromycin at $1 / 4 \times, \mathrm{I} / 2 \times, \mathrm{I} \times, 2 \times, 4 \times$ minimum inhibitory concentration (MIC) and to peak concentrations in epithelial lining fluid (ELF). The secondary aim was to determine the influence of $\mathrm{CO}_{2}$ enriched atmosphere on bacterial susceptibility.
\end{abstract}

Results: Telithromycin showed high activity against $H$. influenzae, including strains susceptible to $\beta$-lactams $(n=200), \beta$-lactamase producer $(n=50)$ and $\beta$-lactamase negative ampicillin resistant (BLNAR) $(n=10)$, with MIC from $\leq 0.03$ to $4 \mathrm{mg} / \mathrm{L}$, and $M \mathrm{C}_{50} / \mathrm{MIC}_{90}$ of $\mathrm{I} / 2 \mathrm{mg} / \mathrm{L}$ with susceptibility rate of $100 \%$, and minimum bactericidal concentrations (MBC) from 2 to 4 -fold higher than the MIC. Azithromycin was the most active tested macrolide (range: $0.25-4 \mathrm{mg} / \mathrm{L} ; \mathrm{MIC}_{50} / \mathrm{MIC}_{90}: \mathrm{I} / 2$ $\mathrm{mg} / \mathrm{L})$, comparable to telithromycin, while clarithromycin showed the highest MICs and MBCs (range: $0.25-8 \mathrm{mg} / \mathrm{L} ; \mathrm{MIC}_{50} / \mathrm{MIC}_{90}: 2 / 8 \mathrm{mg} / \mathrm{L}$ ). In time-kill studies, telithromycin showed a bactericidal activity at the higher concentrations (4-2 $\times$ MIC and ELF) against all the strains, being complete after $12-24$ hours from drug exposition. At MIC concentrations, at ambient air, bactericidal activity of telithromycin and azithromycin was quite similar at I 2 hours, and better than that of clarithromycin. Besides, telithromycin and clarithromycin at ELF concentrations were bactericidal after 12 hours of incubation for most strains, while 24 hours were needed to azithromycin to be bactericidal. Incubation in $\mathrm{CO}_{2}$ significantly influenced the MICs and MBCs, and only slightly the in vitro killing curves.

Conclusion: Telithromycin showed an in-vitro potency against $H$. influenzae comparable to azithromycin, with an in-vitro killing rate more rapid and superior to clarithromycin at 2X-MIC against $\beta$-lactamase producers and BLNAR strains, and to azithromycin at ELF concentrations against $\beta$-lactamase negative strains. Against all strains, MICs and MBCs were lower in the absence of $\mathrm{CO}_{2}$ for the tested antibiotics, showing an adverse effect of incubation in a $\mathrm{CO}_{2}$ environment. The in-vitro potency together with the tissue concentrations of the antimicrobial, should be considered in predicting efficacy. 


\section{Background}

Telithromycin has been the first ketolide to be approved for clinical use, specifically developed for treatment of community acquired respiratory tract infections (CARTI) in order to overcome the spreading of resistance to macrolides among pneumococci $[1,2]$. In comparison to macrolides, telithromycin shows notable improvements in antimicrobial and pharmacokinetic properties, even if it shares with macrolides the same bacterial target, represented by the ribosome [2]. Particularly, telithromycin has significantly lower minimum inhibitory concentration (MIC) than the macrolide antibiotics for many gram-positive organisms, i.e Streptococcus. pneumoniae that shows, at the ribosome, a dual-site binding to the drug [3].

Telithromycin is a concentration-dependent antibiotic, thus the concentrations achieved at the infection site are recognized as an important determinant of efficacy [4]. Due to the ability to penetrate into white blood cells and being characterized by high penetration rate, it may be delivered to sites of infections and reaches elevated concentrations in several tissues, particularly in the respiratory tract, comparable to those of macrolides and superior to $\beta$-lactams $[5,6]$. H. influenzae, a major cause of CARTI [7-10], demonstrates relatively good in vitro susceptibility to macrolides, azalides and ketolides, which show a unimodal MIC distribution and low prevalence of high level resistance when defined by current Clinical and Laboratory Standards Institute (CLSI) breakpoints [11].

Macrolides and azalides are currently recommended for treatment of community acquired pneumonia and acute exacerbations of chronic bronchitis, with the antipneumococcal fluoroquinolones, such as levofloxacin and moxifloxacin, as alternative agents in the most severe cases [12-16].

Due to the fact that the bactericidal activity of macrolides and ketolides is related to the level of drug concentration in the infected tissue $[15,16]$, the evaluation of antibacterial activity of concentrations achievable in vivo, particularly in epithelial lining fluid (ELF), against $H$. influenzae, which is one of the most common pathogen of these anatomical districts, may provide further information on telithromycin activity. Carbon dioxide has been proved to affect antibacterial activity of macrolides and ketolides, when assessed by determination of MIC values [17-20]. Influence of $\mathrm{CO}_{2}$ on bactericidal activity of ketolides and macrolides as measured by time kill curves has been less investigated.

The present study aimed mainly to evaluate the antibacterial activity of telithromycin concentration achievable in ELF against $H$. influenzae clinical isolates with different pattern of resistance, in comparison with azithromycin and clarithromycin and the influence of $\mathrm{CO}_{2}$ incubation on activity of telithromycin and macrolides.

\section{Methods \\ Microorganisms}

$H$. influenzae strains isolated from respiratory tract infections with the following phenotypes were tested: $\beta$-lactamase negative strains $(n=200), \beta$-lactamase producer strains $(\mathrm{n}=50)$, and $\beta$-lactamase negative ampicillin resistant (BLNAR) strains $(\mathrm{n}=10)$. In order to avoid duplicate strains, only one isolate for each patient was considered. The strains were stored at $-80^{\circ} \mathrm{C}$ in Haemophilus test medium (HTM) broth (Labobasi, Novazzano, $\mathrm{CH})$, supplemented with $10 \%$ glycerol before testing and checked for purity throughout the study by culture and Gram staining

\section{Drugs}

The following antibiotics, as pure substances or powder of stated potency, were considered: telithromycin (sanofiaventis, Milan, Italy), azithromycin (Pfizer, Rome, Italy) and clarithromycin (Abbott Italy, Rome, Italy). Stock solutions of antibiotics were prepared in 95\% ethanol (azithromycin) and methanol (clarithromycin and telithromycin) at concentrations of $5120 \mathrm{mg} / \mathrm{L}$ and stored in aliquots at $-20^{\circ} \mathrm{C}$ until use. Epithelial lining fluid concentrations tested by time kill curve assay were chosen from literature data and were equal to $3.12 \mathrm{mg} / \mathrm{L}$ for azithromycin, $34 \mathrm{mg} / \mathrm{L}$ for clarithromycin and $5.4 \mathrm{mg} / \mathrm{L}$ for telithromycin [21-23]. Concentration values for all tested drugs were chosen on the basis of similar study conditions. In particular, studies on healthy volunteers were selected for this in vitro investigation due to the frequent inter-individual pharmacokinetics variability in patients

\section{Determination of minimum inhibitory concentration (MIC) and minimum bactericidal concentration (MBC)}

Antibiotic susceptibilities to all the tested drugs were determined using a broth microdilution method according to the CLSI Approved Standards [24,25].

An adjusted inoculum of the tested organism was inoculated into Haemophilus test medium broth containing two fold serial dilutions of a starting antibiotic solution, so that each well contained approximately $5 \times 10^{5} \mathrm{cfu} / \mathrm{mL}$. Results were observed after $18 \mathrm{~h}$ of incubation at $37^{\circ} \mathrm{C}$ and MIC was defined as the lowest concentration able to inhibit visible growth. Determination of MIC values were performed both in presence and in absence of $10 \% \mathrm{CO}_{2}$. $\mathrm{MBC}$ was determined by plating $0.010 \mathrm{~mL}$ from the wells showing no visible growth on agar plates and incubating for $18-24 \mathrm{~h}$ in $10 \% \mathrm{CO}_{2}$ enriched atmosphere which assures the best environment for growth of $H$. influenzae. $\mathrm{MBC}$ was considered as the concentration at which a 99.9\% reduction in cfu occurred, when compared with 
Table I: MIC values of $H$. influenzae strains

\begin{tabular}{|c|c|c|c|c|c|c|c|}
\hline \multirow[t]{3}{*}{ Microorganisms } & \multirow[t]{3}{*}{ Drug } & \multicolumn{6}{|c|}{ MIC } \\
\hline & & \multicolumn{3}{|c|}{ Ambient air } & \multicolumn{3}{|c|}{$\mathrm{CO}_{2}$} \\
\hline & & Range (mg/L) & $M I C_{50} / M / C_{90}(m g / L)$ & S (\%)\# & Range (mg/L) & $M / C_{50} / M / C_{90}(\mathrm{mg} / \mathrm{L})$ & $S(\%) \#$ \\
\hline \multirow[t]{3}{*}{$\beta$-lactamase negative $(n=200)$} & Tel§ & $0.03-4$ & $\mathrm{I} / 2$ & 100 & $0.06-16$ & $2 / 8$ & 82 \\
\hline & Clr & $0.25-8$ & $2 / 8$ & 100 & $1-16$ & $8 / 16$ & 91 \\
\hline & Azm & $0.25-2$ & $1 / 2$ & 100 & $0.5-8$ & $2 / 4$ & 88 \\
\hline \multirow[t]{3}{*}{$\beta$-lactamase positive $(n=50)$} & Tel & $0.06-4$ & $1 / 2$ & 100 & $0.125-8$ & $2 / 8$ & 87 \\
\hline & Clr & $0.5-8$ & $2 / 8$ & 100 & $1-16$ & $8 / 16$ & 89 \\
\hline & Azm & $0.25-2$ & $\mathrm{I} / 2$ & 100 & $0.5-8$ & $2 / 4$ & 89 \\
\hline \multirow[t]{3}{*}{$\operatorname{BLNAR*}(n=10)$} & Tel & $0.06-4$ & $1 / 4$ & 100 & $0.125-8$ & $2 / 8$ & 90 \\
\hline & Clr & $1-8$ & $1 / 8$ & 100 & $2-16$ & $8 / 16$ & 90 \\
\hline & Azm & $0.25-4$ & $1 / 4$ & 100 & $0.5-8$ & $2 / 8$ & 80 \\
\hline
\end{tabular}

*: BLNAR: $\beta$-lactamase negative ampicillin resistant; §: Tel: telithromycin; Clr: Clarithromycin; Azm: Azithromycin. \# S:susceptible strains according to CLSI breakpoints: Telithromycin: susceptibility: $\leq 4 \mathrm{mg} / \mathrm{L}$, resistance: $\geq 16 \mathrm{mg} / \mathrm{L}$; Clarithromycin: susceptibility: $\leq 8 \mathrm{mg} / \mathrm{L}$, resistance: $\geq 32 \mathrm{mg} / \mathrm{L}$;

Azithromycin: susceptibility: $\leq 4 \mathrm{mg} / \mathrm{L}$.

the original inoculum. For each analytical series, quality controls were carried out with H. influenzae ATCC 49247 strains. To interpret MIC results, susceptibility breakpoints from CLSI were used: susceptible MIC $\leq 4 \mathrm{mg} / \mathrm{L}, \leq$ $8 \mathrm{mg} / \mathrm{L}, \leq 4 \mathrm{mg} / \mathrm{L}$ for azithromycin, clarithromycin and telithromycin respectively, resistant MIC $>4 \mathrm{mg} / \mathrm{L},>32$ $\mathrm{mg} / \mathrm{L}$ and $>16 \mathrm{mg} / \mathrm{l}$ for azithromycin, clarithromycin and telithromycin, respectively.

\section{Time kill curves}

Bactericidal activity of drugs under study were evaluated by performing time kill curves experiments on all $H$. influenzae strains. HTM broth containing drug concentrations equivalent to $1 / 4 \times \mathrm{MIC}, 1 / 2 \times \mathrm{MIC} ; 1 \times \mathrm{MIC}, 2 \times \mathrm{MIC}, 4$ $\times$ MIC and to peak concentrations reachable by each drug in ELF was inoculated with $5 \times 10^{5}-5 \times 10^{6} \mathrm{cfu} / \mathrm{mL}$, and incubated at $37^{\circ} \mathrm{C}$ in presence or absence of $10 \% \mathrm{CO}_{2}$. Viability counts of antibiotic containing suspensions and controls, lacking antibiotic, were obtained at 0, 3, 612 and $24 \mathrm{~h}$ by plating 10 -fold dilutions of $0.1 \mathrm{~mL}$ aliquots from each tube onto chocolate agar plates, which were incubated for up to $48 \mathrm{~h}$ in $\mathrm{CO}_{2}$ enriched atmosphere at $37^{\circ} \mathrm{C}$. A given concentration of antibiotic was considered bactericidal if it reduced the inoculum viable count by $\geq 3$ $\log _{10} \mathrm{CFU} / \mathrm{mL}$, or bacteriostatic if it reduced the inoculum viable count by $<3 \log \mathrm{CFU} / \mathrm{mL}$

\section{Results}

Antibacterial activity of azithromycin, clarithromycin and telithromycin against $H$. influenzae expressed as MIC and $\mathrm{MBC}$ values and rate of susceptibility is depicted in Tables 1 and 2, where data obtained by incubating bacteria at ambient air or at $10 \% \mathrm{CO}_{2}$ are summarized. Telithromycin in ambient air showed activity against all the tested $H$. influenzae strains, with MIC values ranging from $\leq 0.03$ to $4 \mathrm{mg} / \mathrm{L}$, and susceptibility rates of $100 \%$, similar to the azithromycin rates.

Table 2: MBC values of $H$. influenzae strains

\begin{tabular}{|c|c|c|c|c|c|}
\hline \multirow[t]{2}{*}{ Microorganisms } & \multirow[t]{2}{*}{ Drug } & \multicolumn{2}{|c|}{ Ambient air } & \multicolumn{2}{|r|}{$\mathrm{CO}_{2}$} \\
\hline & & Range (mg/L) & $M B C_{50} / M B C_{90}(\mathrm{mg} / \mathrm{L})$ & Range (mg/L) & $M B C_{50} / M B C_{90}(\mathbf{m g} / \mathrm{L})$ \\
\hline \multirow[t]{3}{*}{$\beta$-lactamase negative $(n=200)$} & Tel§ & $0.125-16$ & $\mathrm{I} / 4$ & $0.06-32$ & $4 / 16$ \\
\hline & Clr & $0.25-64$ & $4 / 16$ & $1-128$ & $8 / 64$ \\
\hline & Azm & $0.25-8$ & $1 / 4$ & $0.5-64$ & $4 / 8$ \\
\hline \multirow[t]{3}{*}{$\beta$-lactamase positive $(n=50)$} & Tel & $0.125-8$ & $1 / 4$ & $0.125-16$ & $4 / 16$ \\
\hline & Clr & $0.5-32$ & $4 / 16$ & $1-64$ & $8 / 64$ \\
\hline & Azm & $0.25-8$ & $1 / 4$ & $0.5-32$ & $4 / 8$ \\
\hline \multirow[t]{3}{*}{$\operatorname{BLNAR}^{*}(\mathrm{n}=10)$} & Tel & $0.125-8$ & $1 / 8$ & $0.25-8$ & $4 / 8$ \\
\hline & Clr & $1-16$ & $4 / 16$ & $2-32$ & $8 / 32$ \\
\hline & Azm & $0.25-8$ & $1 / 8$ & $0.5-16$ & $4 / 16$ \\
\hline
\end{tabular}

*: BLNAR: $\beta$-lactamase negative ampicillin resistant; §: Tel: telithromycin; Clr: Clarithromycin; Azm: Azithromycin. 
Generally, MICs and MBCs against $\beta$-lactamase negative $H$. influenzae strains were lower in absence of $\mathrm{CO}_{2}$ for all the tested antibiotics, with a decrease from 2 to 4 fold in respect to the $\mathrm{CO}_{2}$ incubation, being $\mathrm{MIC}_{50} / \mathrm{MIC}_{90} 2 / 8$ and $1 / 2 \mathrm{mg} / \mathrm{L}$ for telithromycin, $8 / 16$ and $2 / 8 \mathrm{mg} / \mathrm{L}$ for clarithromycin, $2 / 4$ and $1 / 2 \mathrm{mg} / \mathrm{L}$ for azithromycin, after incubation with or without $\mathrm{CO}_{2}$, respectively.

The MBCs of telithromycin were closer to the MIC values with respect to the two comparators. $\mathrm{MBC}_{50} / \mathrm{MBC}_{90}$ were $4 / 16$ and $1 / 4 \mathrm{mg} / \mathrm{L}$ for telithromycin, $8 / 64$ and $4 / 16 \mathrm{mg} /$ $\mathrm{L}$ for clarithromycin, $4 / 8$ and $1 / 4 \mathrm{mg} / \mathrm{L}$ for azithromycin after incubation with or without $\mathrm{CO}_{2}$, respectively. In absence of $\mathrm{CO}_{2}$, all the strains were fully susceptible to the study drugs (100\%). After incubation in $\mathrm{CO}_{2}$, the susceptibility rate was generally decreased (from $82 \%$ of telithromycin to $91 \%$ of clarithromycin), showing an interfering effect of this particular medium. The non-susceptible strains were included into the I (Intermediate) category, with the exclusion of 3 strains resistant to telithromycin. Similar results were observed for $\beta$-lactamase positive $H$. influenzae strains with $\mathrm{MIC}_{50}, \mathrm{MIC}_{90}, \mathrm{MBC}_{50}$ and $\mathrm{MBC}_{90}$ equal to those observed for $\beta$-lactamase negative strains. The microbiological activity of telithromycin was not significantly affected by $\beta$-lactamase production. Also in this case, the addition of $\mathrm{CO}_{2}$ to the medium influenced the microbiological results, in terms of MIC and MBC values and susceptibility rates: $100 \%$ of susceptibility in open air for all the tested drugs, 87 and $89 \%$ in $\mathrm{CO} 2$ respectively for telithromycin and macrolides.

The 10 BLNAR strains were fully susceptible to the antibiotics in open air medium. In $\mathrm{CO}_{2}$ atmosphere, MIC and $\mathrm{MBC}$ were higher in presence of $\mathrm{CO}_{2}$ for all the tested antibiotics; the activity of telithromycin and clarithromycin was slightly superior to that of azithromycin being the susceptibility rate $90 \%, 90 \%$ and $80 \%$, respectively.

Results obtained in time-kill curves for azithromycin, clarithromycin and telithromycin against $\beta$-lactamase-negative, $\beta$-lactamase-positive and BLNAR $H$. influenzae are shown in Figures 1, 2, 3 and in Tables 3, 4, 5. Bactericidal activities of telithromycin, clarithromycin and azithromycin against $H$. influenzae were similar, independently from the pattern of resistance. All these drugs were fully bactericidal after 12 hours at concentration of $4 \times \mathrm{MIC}$ and after 24 hours at the highest concentrations $(2-4 \times \mathrm{MIC}$, and ELF) against $\beta$-lactamase-negative strains (Figure 1, Table 3). Telithromycin and clarithromycin were bactericidal after 12 hours of incubation also at ELF concentration, while at the same time, azithromycin was bactericidal at 2 $\times$ MIC (Figure 1).

Similar trends in bactericidal activities were observed for $\beta$-lactamase producer and BLNAR strains (Figures 2 and 3, Tables 4 and 5).

Table 3: Time kill curve against $\beta$-lactamase negative $H$. influenzae strains $(\mathbf{N}=\mathbf{2 0 0})$

\begin{tabular}{|c|c|c|c|c|c|c|c|c|c|}
\hline \multirow[t]{3}{*}{ Antibiotic } & & \multicolumn{8}{|c|}{ Mean changes in colony counts vs initial inocula after } \\
\hline & & \multicolumn{2}{|c|}{$3 \mathrm{~h}$} & \multicolumn{2}{|c|}{$6 \mathrm{~h}$} & \multicolumn{2}{|c|}{$12 \mathrm{~h}$} & \multicolumn{2}{|c|}{$24 \mathrm{~h}$} \\
\hline & & $\mathrm{CO}_{2}$ & Air & $\mathrm{CO}_{2}$ & Air & $\mathrm{CO}_{2}$ & Air & $\mathrm{CO}_{2}$ & Air \\
\hline \multirow[t]{6}{*}{ Telithromycin } & $4 \times \mathrm{MIC}$ & -1.42 & -1.72 & -2.81 & -2.61 & $>-3.0$ & $>-3.0$ & $>-3.0$ & $>-3.0$ \\
\hline & $2 \times \mathrm{MIC}$ & -0.64 & -0.18 & -1.87 & -1.91 & -2.71 & -2.45 & $>-3.0$ & $>-3.0$ \\
\hline & $\mathrm{I} \times \mathrm{MIC}$ & -0.36 & -0.15 & -0.99 & -0.26 & -1.21 & -1.18 & -1.32 & -1.81 \\
\hline & $\mathrm{I} / 2 \times \mathrm{MIC}$ & 0.22 & 0.39 & 1.20 & 0.85 & 2.27 & 2.43 & 3.74 & 4.12 \\
\hline & $\mathrm{I} / 4 \times \mathrm{MIC}$ & 0.43 & 0.35 & 1.51 & 1.35 & 2.94 & 2.54 & 4.93 & 4.59 \\
\hline & ELF & -1.43 & -1.54 & -2.43 & $>-3.0$ & $>-3.0$ & $>-3.0$ & $>-3.0$ & $>-3.0$ \\
\hline \multirow[t]{6}{*}{ Clarithromycin } & $4 \times \mathrm{MIC}$ & -1.03 & -0.94 & -2.18 & -2.32 & $>-3.0$ & $>-3.0$ & $>-3.0$ & $>-3.0$ \\
\hline & $2 \times M I C$ & -0.75 & -0.69 & -1.80 & $-|.6|$ & -2.42 & -2.30 & $>-3.0$ & $>-3.0$ \\
\hline & $\mathrm{I} \times \mathrm{MIC}$ & -0.23 & -0.49 & -0.75 & 0.66 & -0.91 & -1.04 & -1.18 & -1.58 \\
\hline & $\mathrm{I} / 2 \times \mathrm{MIC}$ & -0.19 & -0.19 & 0.69 & 0.66 & 1.57 & 2.71 & 3.81 & 4.31 \\
\hline & $\mathrm{I} / 4 \times \mathrm{MIC}$ & 0.51 & 0.45 & 1.69 & 1.40 & 2.93 & 2.99 & 5.01 & 4.84 \\
\hline & ELF & -1.09 & -1.26 & -2.68 & $>-3.0$ & $>-3.0$ & $>-3.0$ & $>-3.0$ & $>-3.0$ \\
\hline \multirow[t]{6}{*}{ Azithromycin } & $4 \times M I C$ & -1.99 & -1.38 & -2.86 & -2.44 & $>-3.0$ & $>-3.0$ & $>-3.0$ & $>-3.0$ \\
\hline & $2 \times M I C$ & -0.98 & -0.94 & -1.73 & -1.88 & $>-3.0$ & -2.57 & $>-3.0$ & $>-3.0$ \\
\hline & $\mathrm{I} \times \mathrm{MIC}$ & -0.10 & -0.06 & -0.56 & -0.45 & -1.55 & -1.84 & -1.80 & -1.99 \\
\hline & $\mathrm{I} / 2 \times \mathrm{MIC}$ & 0.18 & 0.29 & 0.91 & 1.03 & 1.71 & 2.31 & 3.49 & 3.41 \\
\hline & $\mathrm{I} / 4 \times \mathrm{MIC}$ & 0.39 & 0.36 & 1.38 & 1.63 & 2.23 & 2.53 & 4.58 & 4.28 \\
\hline & ELF & -0.45 & -1.22 & -2.40 & -2.12 & -2.72 & -2.55 & $>-3.0$ & $>-3.0$ \\
\hline Control & & 0.64 & 0.38 & 1.96 & 1.95 & 4.32 & 3.05 & 5.44 & 4.90 \\
\hline
\end{tabular}


Table 4: Time kill curve against $\beta$-lactamase positive $H$. influenzae $(n=50)$

\begin{tabular}{|c|c|c|c|c|c|c|c|c|c|}
\hline \multirow[t]{3}{*}{ Antibiotic } & & \multicolumn{8}{|c|}{ Changes in colony counts vs initial inocula after } \\
\hline & & \multicolumn{2}{|c|}{$3 \mathrm{~h}$} & \multicolumn{2}{|c|}{$6 \mathrm{~h}$} & \multicolumn{2}{|c|}{$12 \mathrm{~h}$} & \multicolumn{2}{|c|}{$24 \mathrm{~h}$} \\
\hline & & $\mathrm{CO}_{2}$ & Air & $\mathrm{CO}_{2}$ & Air & $\mathrm{CO}_{2}$ & Air & $\mathrm{CO}_{2}$ & Air \\
\hline \multirow[t]{6}{*}{ Telithromycin } & $4 \times$ MIC & -1.28 & -1.44 & -2.74 & -2.80 & $>-3.0$ & $>-3.0$ & $>-3.0$ & $>-3.0$ \\
\hline & $2 \times \mathrm{MIC}$ & -0.37 & -0.89 & -1.57 & -1.77 & -2.77 & -2.88 & $>-3.0$ & $>-3.0$ \\
\hline & $\mathrm{I} \times \mathrm{MIC}$ & -0.53 & -0.16 & -0.82 & -0.76 & -0.96 & -1.12 & $-|.5|$ & -1.62 \\
\hline & $\mathrm{I} / 2 \times \mathrm{MIC}$ & -0.13 & -0.04 & 1.06 & 0.13 & 1.33 & 1.61 & 3.59 & 2.08 \\
\hline & $\mathrm{I} / 4 \times \mathrm{MIC}$ & 0.33 & 0.41 & 1.66 & 1.29 & 2.46 & 2.74 & 4.03 & 3.19 \\
\hline & ELF & -1.00 & -0.96 & -2.68 & -2.72 & $>-3.0$ & $>-3.0$ & $>-3.0$ & $>-3.0$ \\
\hline \multirow[t]{6}{*}{ Clarithromycin } & $4 \times \mathrm{MIC}$ & -1.47 & -0.88 & -2.00 & -2.22 & $>-3.0$ & $>-3.0$ & $>-3.0$ & $>-3.0$ \\
\hline & $2 \times M I C$ & -0.80 & -0.30 & -1.14 & $-|.5|$ & -1.42 & -1.86 & $>-3.0$ & $>-3.0$ \\
\hline & $\mathrm{I} \times \mathrm{MIC}$ & -0.27 & -0.06 & -0.79 & -0.60 & -1.31 & -1.61 & -1.40 & -1.86 \\
\hline & $\mathrm{I} / 2 \times \mathrm{MIC}$ & 0.52 & 0.45 & 2.43 & 2.42 & 2.36 & 2.38 & 2.63 & 2.84 \\
\hline & $\mathrm{I} / 4 \times \mathrm{MIC}$ & 0.71 & 0.69 & 2.69 & 2.47 & 2.73 & 3.25 & 3.91 & 3.98 \\
\hline & ELF & -0.91 & -1.22 & -2.65 & $>-3.0$ & $>-3.0$ & $>-3.0$ & $>-3.0$ & $>-3.0$ \\
\hline \multirow[t]{6}{*}{ Azithromycin } & $4 \times \mathrm{MIC}$ & -1.49 & -2.22 & -2.61 & -2.85 & $>-3.0$ & $>-3.0$ & $>-3.0$ & $>-3.0$ \\
\hline & $2 \times M I C$ & -0.98 & -1.68 & -1.65 & -1.93 & $>-3.0$ & $>-3.0$ & $>-3.0$ & $>-3.0$ \\
\hline & $\mathrm{I} \times \mathrm{MIC}$ & -1.03 & -0.64 & -1.23 & -0.48 & -1.43 & -0.68 & -1.62 & -0.23 \\
\hline & $\mathrm{I} / 2 \times \mathrm{MIC}$ & -0.67 & -0.15 & -0.03 & 1.86 & 0.47 & 1.93 & 3.67 & 2.18 \\
\hline & $\mathrm{I} / 4 \times \mathrm{MIC}$ & 0.29 & 0.26 & 1.58 & 1.96 & 2.34 & 2.13 & 4.12 & 3.28 \\
\hline & ELF & -1.05 & -1.20 & -2.27 & -2.53 & $>-3.0$ & $>-3.0$ & $>-3.0$ & $>-3.0$ \\
\hline Control & & 0.62 & 0.73 & 2.38 & 2.49 & 4.02 & 4.13 & 4.44 & 4.55 \\
\hline
\end{tabular}

Incubation of the bacterial culture in open air or in $\mathrm{CO}_{2}$ seemed to slightly influence the killing curves, as, globally, no marked differences in bactericidal activity were observed between incubation in the presence or absence of $\mathrm{CO}_{2}$.

Table 5: Time kill curve against $\beta$-lactamase negative-ampicillin resistant $H$. influenzae $(n=10)$

\begin{tabular}{|c|c|c|c|c|c|c|c|c|c|}
\hline \multirow[t]{3}{*}{ Antibiotic } & & \multicolumn{8}{|c|}{ Changes in colony counts vs initial inocula after } \\
\hline & & \multicolumn{2}{|c|}{$3 \mathrm{~h}$} & \multicolumn{2}{|c|}{$6 \mathrm{~h}$} & \multicolumn{2}{|c|}{$12 \mathrm{~h}$} & \multicolumn{2}{|c|}{$24 \mathrm{~h}$} \\
\hline & & $\mathrm{CO}_{2}$ & Air & $\mathrm{CO}_{2}$ & Air & $\mathrm{CO}_{2}$ & Air & $\mathrm{CO}_{2}$ & Air \\
\hline \multirow[t]{6}{*}{ Telithromycin } & $4 \times \mathrm{MIC}$ & -1.53 & -1.96 & -2.38 & -2.69 & $>-3.0$ & $>-3.0$ & $>-3.0$ & $>-3.0$ \\
\hline & $2 \times \mathrm{MIC}$ & -0.68 & -0.30 & -1.55 & -1.96 & -2.82 & -2.84 & $>-3.0$ & $>-3.0$ \\
\hline & $\mathrm{I} \times \mathrm{MIC}$ & -0.38 & -0.56 & -0.88 & -0.66 & -1.23 & -1.27 & -1.66 & -1.37 \\
\hline & $\mathrm{I} / 2 \times \mathrm{MIC}$ & 0.17 & 0.78 & 2.26 & 2.43 & 2.94 & 3.26 & 3.53 & 4.40 \\
\hline & $\mathrm{I} / 4 \times \mathrm{MIC}$ & 0.33 & 0.92 & 2.66 & 2.68 & 3.26 & 3.30 & 3.64 & 4.51 \\
\hline & ELF & -0.55 & -0.92 & -2.85 & -2.89 & $>-3.0$ & $>-3.0$ & $>-3.0$ & $>-3.0$ \\
\hline \multirow[t]{6}{*}{ Clarithromycin } & $4 \times M I C$ & -1.68 & -0.96 & -2.02 & -1.96 & $>-3.0$ & $>-3.0$ & $>-3.0$ & $>-3.0$ \\
\hline & $2 \times \mathrm{MIC}$ & -0.16 & -0.62 & -1.16 & -1.38 & -1.70 & -1.99 & $>-3.0$ & $>-3.0$ \\
\hline & $\mathrm{I} \times \mathrm{MIC}$ & -0.14 & -0.21 & -0.45 & -0.42 & -1.56 & -0.67 & -1.75 & -1.74 \\
\hline & $\mathrm{I} / 2 \times \mathrm{MIC}$ & 0.33 & 0.51 & 1.76 & $\mathrm{I} .34$ & 1.99 & 1.45 & 3.51 & 4.28 \\
\hline & $\mathrm{I} / 4 \times \mathrm{MIC}$ & 0.64 & 0.75 & 2.87 & 2.88 & 3.44 & 3.35 & 4.03 & 4.61 \\
\hline & ELF & -0.71 & -1.36 & -2.43 & -2.62 & $>-3.0$ & $>-3.0$ & $>-3.0$ & $>-3.0$ \\
\hline \multirow[t]{6}{*}{ Azithromycin } & $4 \times \mathrm{MIC}$ & -1.55 & -1.62 & -2.50 & -2.76 & $>-3.0$ & $>-3.0$ & $>-3.0$ & $>-3.0$ \\
\hline & $2 \times M I C$ & -1.16 & -1.37 & -1.90 & -1.96 & $>-3.0$ & $>-3.0$ & $>-3.0$ & $>-3.0$ \\
\hline & $\mathrm{I} \times \mathrm{MIC}$ & -1.01 & -0.56 & -0.90 & -0.89 & -1.68 & -1.06 & -1.78 & -1.59 \\
\hline & $\mathrm{I} / 2 \times \mathrm{MIC}$ & 0.21 & 0.72 & 0.92 & 1.28 & 1.98 & 2.01 & 2.49 & 2.53 \\
\hline & $\mathrm{I} / 4 \times \mathrm{MIC}$ & 0.27 & 0.79 & 2.54 & 2.04 & 3.04 & 3.14 & 3.72 & 4.16 \\
\hline & ELF & -1.12 & -1.40 & -2.57 & -2.73 & -2.83 & $>-3.0$ & $>-3.0$ & $>-3.0$ \\
\hline Control & & 0.97 & 0.98 & 3.07 & 3.01 & 3.87 & 3.46 & 5.05 & 4.68 \\
\hline
\end{tabular}



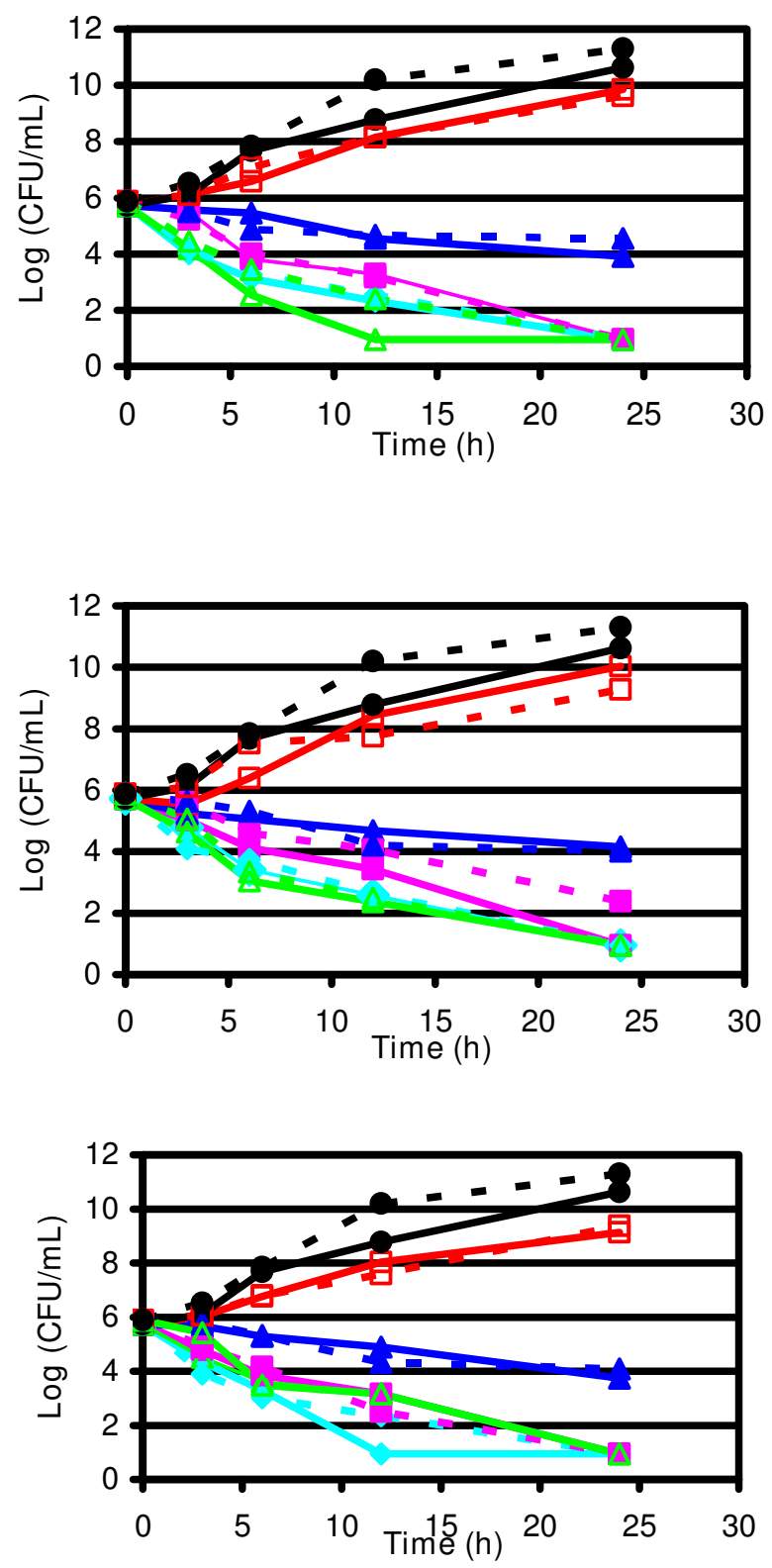

Figure I

Bactericidal activities against $\beta$-lactamase negative $\boldsymbol{H}$. influenzae. Time kill curve of telithromycin (upper), clarithromycin (middle) and azithromycin (lower). black circle: Control growth (no antibiotic); red square: I/2 $\times$ MIC; dark blue triangle: I $\times$ MIC; pink square: $2 \times$ MIC; blue rhomb: $4 \times$ MIC; green triangle: ELF. Full line: ambient air; dashed line: $\mathrm{CO}_{2}$ enriched atmosphere.

\section{Discussion}

The in vitro activity of telithromycin, the first ketolide developed for clinical use, has been widely evaluated in international and local studies, demonstrating a spectrum
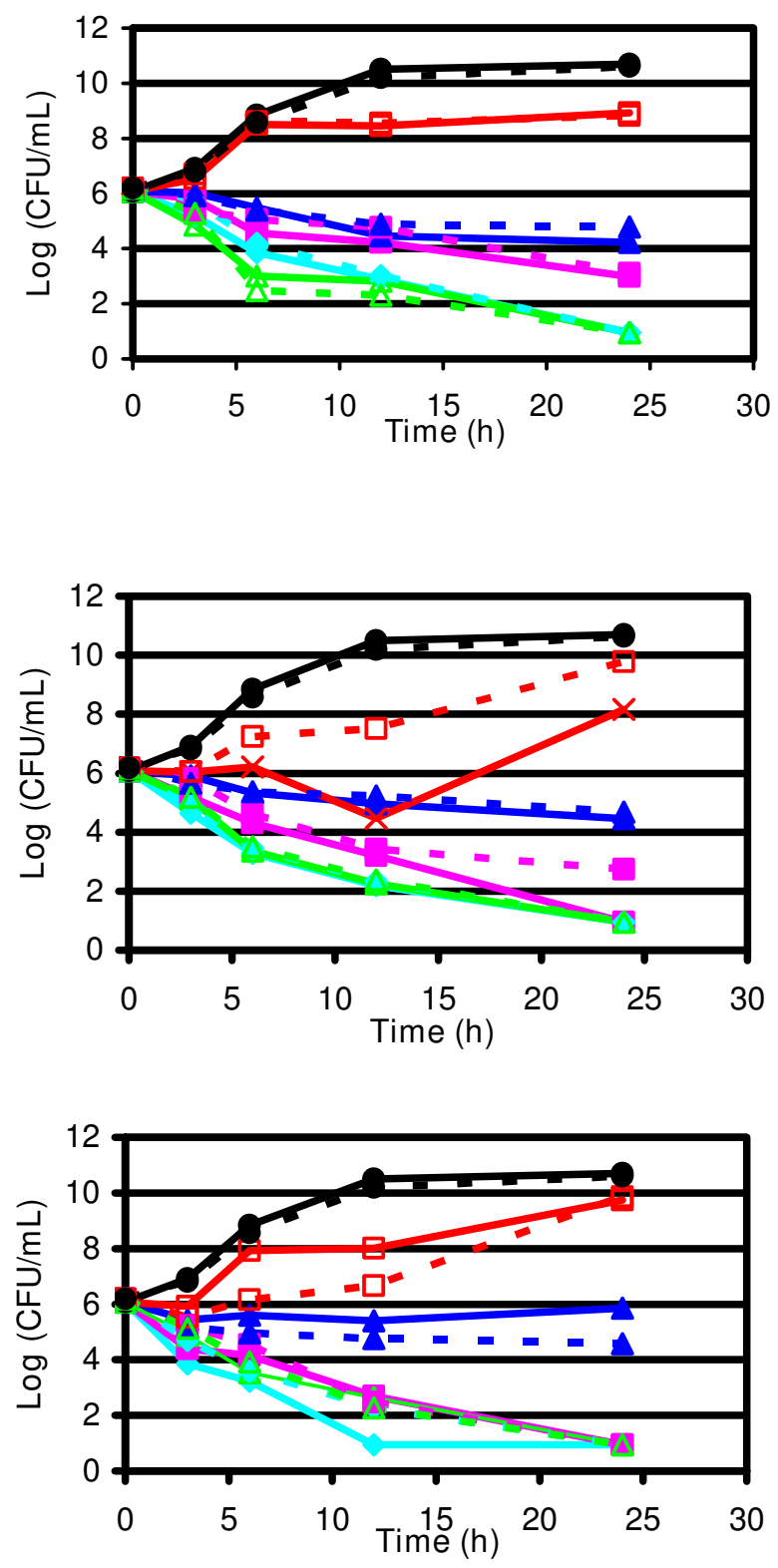

Figure 2

Bactericidal activities against $\beta$-lactamase positive $\boldsymbol{H}$. influenzae. Time kill curve of telithromycin (upper), clarithromycin (middle) and azithromycin (lower). black circle: Control growth (no antibiotic); red square: I/2 $\times$ MIC; dark blue triangle: I $\times$ MIC; pink square: $2 \times$ MIC; blue rhomb: $4 \times$ MIC; green triangle: ELF. Full line: ambient air; dashed line: $\mathrm{CO}_{2}$ enriched atmosphere.

of activity that encompasses the key respiratory pathogens, including $H$. influenzae. As the bactericidal activity of macrolides and ketolides is related to the magnitude of drug concentration at the site of infection, it is instrumen- 

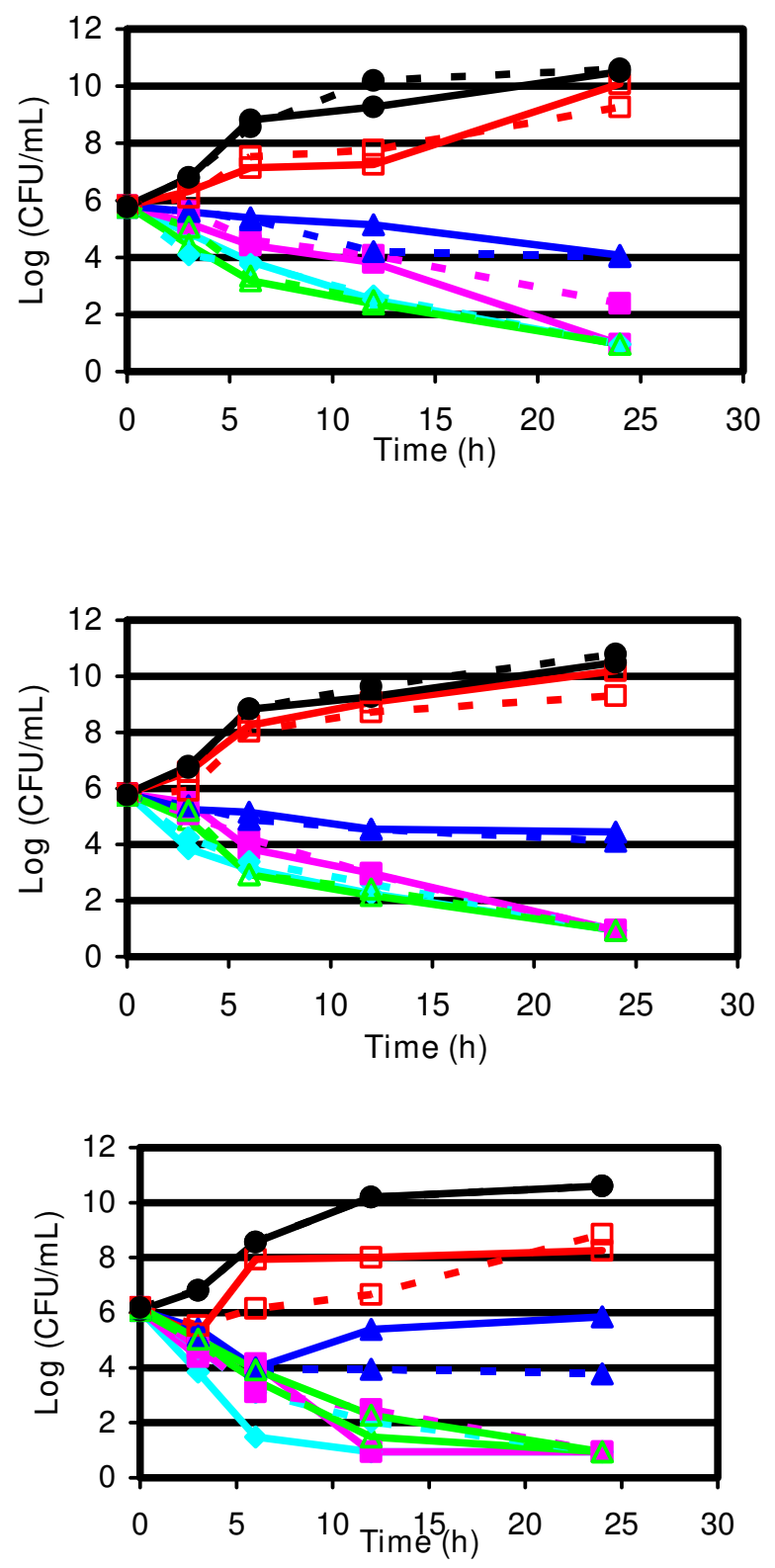

Figure 3

Bactericidal activities against $\beta$-lactamase negative ampicillin resistant $\boldsymbol{H}$. influenzae. Time kill curve of telithromycin (upper), clarithromycin (middle) and azithromycin (lower). black circle: Control growth (no antibiotic); red square: I/2 × MIC; dark blue triangle: I × MIC; pink square: 2 $\times$ MIC; blue rhomb: $4 \times$ MIC; green triangle: ELF. Full line: ambient air; dashed line: $\mathrm{CO}_{2}$ enriched atmosphere.

tal the evaluation of antimicrobial activity of concentrations achievable in vivo at the bronchial tree. Thus the present study assessed the comparative in vitro bacteriological activity and the killing kinetics of telithromycin, azithromycin and clarithromycin against $H$. influenzae at concentrations multiple of the MIC and equal to ELF.

Telithromycin in ambient air showed activity against all the tested $H$. influenzae strains, with susceptibility rates of $100 \%$, similar to azithromycin. The respective MBCs were from 2 to 4 fold higher than the MIC, generally lower than the comparators. Previous in vitro studies have already showed that the in vitro potency against $H$. influenzae of telithomycin is similar to azithromycin, considered the most active macrolide against this pathogen, and superior to clarithomycin $[7,11,26-33]$.

The incubation in carbon dioxide affected the antibacterial activity of all the tested antibiotics, causing a notable increase in MICs and MBCs, resulting in a decreased rate of susceptibility among $H$. influenzae strains.

Susceptibility testing of respiratory tract pathogens is often performed in a $\mathrm{CO}_{2}$ environment to ensure that the bacteria grow faster; however in this ambient the $\mathrm{pH}$ of the test medium decrease and macrolides and telithromycin activity seems adversely affected by this $\mathrm{pH}$ decrease. Thus the results of our study show that telithromycin susceptibility should be tested in ambient air, as well as that of macrolides. Notably, other recent in vitro studies have highlighted the adverse impact of $\mathrm{CO}_{2}$ on susceptibility testing of telithromycin in key respiratory pathogens including $H$. influenzae [17-19].

Few studies have evaluated the bactericidal activity of telithromycin alone or in comparison with macrolides against respiratory pathogens, and in particular against $H$. influenzae $[8,32,33]$. Our data confirm the results of these studies, indicating that the bactericidal activity of telithromycin is mainly evident at concentrations as high as twice and four times the MIC. For all the tested antibiotics the killing of $H$. influenzae was not affected by different resistance patterns of the strains included into the study. When MIC concentrations were considered, bactericidal activities of the studied drugs were quite similar, with azithromycin showing a more rapid killing at $2 \times$ MIC. However, although not fully bactericidal, activity of telithromycin against $H$. influenzae seemed superior in comparison with that of clarithromycin and close to that of azithromycin. By contrast, when bactericidal activity of pulmonary concentrations was tested, telithromycin and clarithromycin showed a higher rate of killing than azithromycin on some strains, probably due to the inferior tissue distribution of this drug.

As both telithromycin and azithromycin are concentration dependent antibiotics, their penetration rate in site infection is an important determinant in predicting efficacy, thus MIC, breakpoints of macrolides, azalides and 
ketolides against this organism must be considered together with their levels in respiratory tissues and ELF. There is growing evidence that, even though MICs for macrolides against $H$. influenzae may be in the 'susceptible' range (as defined by current MIC breakpoints), in vivo bacteriological efficacy is poor against this pathogen, while PK/PD derived breakpoints seems to be more consistent with clinical outcomes [34]. For both clarithromycin and azithromycin, the PK/PD breakpoint is five doubling dilutions lower than the CLSI breakpoint [35], while for telithromycin a breakpoint of $0.5 \mathrm{mg} / \mathrm{L}$ has been proposed [36]. By considering these values, all the strains evaluated in the present study should be considered resistant to the two macrolides, while some of them should be classified as susceptible to telithromycin. However, determination of PK/PD breakpoints is usually based on serum concentrations chosen for optimal bacterial eradication and may not reflect the actual concentration at the site of infection, as occurs for the tested drugs which provide higher concentrations in the lungs than in other compartments, thus allowing higher susceptibility breakpoints when treating pulmonary infections.

\section{Conclusion}

In conclusion, telithromycin showed an in-vitro potency against $H$. influenzae comparable to azithromycin, with a superior in-vitro killing rate to clarithromycin at $2 \mathrm{X}-\mathrm{MIC}$ against $\beta$-lactamase producers and BLNAR strains, and to azithromycin at ELF concentrations against $\beta$-lactamase negative strains. Against all strains, MICs and MBCs were lower in the absence of $\mathrm{CO}_{2}$ for the tested antibiotics, showing an adverse effect of incubation in a $\mathrm{CO}_{2}$ environment. The in-vitro potency together with the pharmacokinetic profile of the antimicrobial, should be considered in predicting its efficacy in the empirical therapy of CARTI.

\section{Competing interests}

LD received research funding from sanofi aventis.

\section{Authors' contributions}

LD participated in design and coordination of the study, interpretation of the data, and co-drafted the manuscript. EDV participated in study design, co-performed killing curves, analysis and interpretation of the data and codrafted the manuscript. LN co-performed time kill curves and participated in analysis and interpretation of the data. ML participated in revising the manuscript.

\section{All authors read and approved the final manuscript.}

\section{Acknowledgements}

The work was supported by an unrestricted grant from sanofi-aventis Italy.

\section{References}

I. Lonks JR, Goldmann DA: Telithromycin: a ketolide antibiotic for treatment of respiratory tract infections. Clin Infect Dis 2005, 40: I657-1664.

2. Ackermann G, Rodloff AC: Drugs of the 2 I st $^{\text {s }}$ century: telithromycin (HMR 3647)-the first ketolide. J Antimicrob Chemother 2003, 5 I:497-5 II.

3. Douthwaite S, Champney WS: Structures of ketolides and macrolides determine their mode of interaction with the ribosomal target site. J Antimicrob Chemother 200I, 48(Suppl TI): I-8.

4. Nicolau DP: Clinical use of antimicrobial pharmacodynamic profiles to optimise treatment outcomes in communityacquired bacterial respiratory tract infections: application to telithromycin. Expert Opin Pharmacother 2004, 5:229-235.

5. Ong CT, Dandekar PK, Sutherland C, Nightingale CH, Nicolau DP: Intrapulmonary concentrations of telithromycin: clinical implications for respiratory tract infections due to Streptococcus pneumoniae. Chemotherapy 2005, 5 I:339-346.

6. Shi J, Montay G, Bhargava VO: Clinical pharmacokinetics of telithromycin, the first ketolide antibacterial. Clin Pharmacokinet 2005, 44:915-934.

7. Murphy TF: The role of bacteria in airway inflammation in exacerbations of chronic obstructive pulmonary disease. Curr Opin Infect Dis 2006, 19:225-230.

8. Murphy TF: Haemophilus influenzae in chronic bronchitis. Semin Respir Infect 2000, I 5:4I-5I.

9. de Roux A, Ewig S, Garcia E, Marcos MA, Mensa J, Lode H, Torres A: Mixed community-acquired pneumonia in hospitalised patients. Eur Respir J 2006, 27:795-800.

10. Huang HH, Zhang YY, Xiu QY, Zhou X, Huang SG, Lu Q, Wang DM, Wang F: Community-acquired pneumonia in Shanghai, China: microbial etiology and implications for empirical therapy in a prospective study of $\mathbf{3 8 9}$ patients. Eur J Clin Microbiol Infect Dis 2006, 25:369-374.

II. Bogdanovich T, Bozdogan B, Appelbaum PC: Effect of efflux on telithromycin and macrolide susceptibility in Haemophilus influenzae. Antimicrob Agents Chemother 2006, 50:893-898.

12. Mandell LA, Bartlett JG, Dowell SF, File TM Jr, Musher DM, Whitney C, Infectious Diseases Society of America: Update of practice guidelines for the management of community-acquired pneumonia in immunocompetent adults. Clin Infect Dis 2003. 37:|405-1433.

13. Martin SJ, Sahloff EG, Close SJ: Evaluation and cost assessment of fluoroquinolones in community-acquired respiratory infections. Expert Opin Pharmacother 2002, 3: I 25।-1266.

14. Neafsey PJ: Ketolides: new antimicrobials for communityacquired pneumonia. Home Healthc Nurse 2005, 23:|4|-|43.

15. Niederman MS: Principles of appropriate antibiotic use. Int J Antimicrob Agents 2005, 26(Suppl 3):SI70-I75.

16. Niederman MS, Chang JR, Stewart J, Asche CV, Lavin B, Nusrat R, Sullivan SD: Hospitalization rates among patients with community-acquired pneumonia treated with telithromycin vs clarithromycin: results from two randomized, double-blind, clinical trials. Curr Med Res Opin 2004, 20:969-980.

17. Bouchillon SK, Johnson JL, Hoban DJ, Stevens TM, Johnson BM: Impact of carbon dioxide on the susceptibility of key respiratory tract pathogens to telithromycin and azithromycin. J Antimicrob Chemother 2005, 56:224-227.

18. Batard E, Juvin ME, Jacqueline C, Bugnon D, Caillon J, Potel G, Drugeon $\mathrm{HB}$ : Influence of carbon dioxide on the MIC of telithromycin for Streptococcus pneumoniae: an in vitro-in vivo study. Antimicrob Agents Chemother 2005, 49:464-466.

19. Walsh F, Carnegy F, Willcock J, Amyes S: Comparative in vitro activity of telithromycin against macrolide-resistant and susceptible Streptococcus pneumoniae, Moraxella catarrhalis and Haemophilus influenzae. I Antimicrob Chemother 2004, 53:793-796.

20. Bemer-Melchior P, Juvin ME, Tassin S, Bryskier A, Schito GC, Drugeon $\mathrm{HB}$ : In vitro activity of the new ketolide telithromycin compared with those of macrolides against Streptococcus pyogenes: influences of resistance mechanisms and methodological factors. Antimicrob Agents Chemother 2000, 44:2999-3002.

21. Olsen KM, San Pedro G, Gann LP, Gubbins PO, Halinski DM, Campbell GD Jr: Intrapulmonary pharmacokinetics of azithromycin in healthy volunteers given five oral doses. Antimicrob Agents Chemother 1996, 40:2582-2585. 
22. Patel KB, Xuan D, Tessier PR, Russomanno JH, Quintiliani R, Nightingale $\mathrm{CH}$ : Comparison of bronchopulmonary pharmacokinetics of clarithromycin and azithromycin. Antimicrob Agents Chemother 1996, 40:2375-2379.

23. Muller-Serieys C, Andrews J, Vacheron F, Cantalloube C: Tissue kinetics of telithromycin, the first ketolide antibacterial. J Antimicrob Chemother 2004, 53:149-157.

24. Clinical and Laboratory Standards Institute (CLSI): Methods for Dilution Antimicrobial Susceptibility Tests for Bacteria That Grow Aerobically; Approved Standard. Document M7-A6 Wayne, PA: CLSI; 2003.

25. Clinical and Laboratory Standards Institute (CLSI): Performance standards for antimicrobial susceptibility testing. Document MI00-SI5 Wayne, PA: CLSI; 2005.

26. Okamoto H, Myazaki S, Tateda $K$, Ishii $Y$, Yamaguchi $K$ : In vivo efficacy of telithromycin against Streptococcus pneumoniae and Haemophilus influenzae. Antimicrob Agents and Chemother 200I, 45:3250-3252.

27. Dabernat $\mathrm{H}$, Seguy M, Delmas $\mathrm{C}$ : In vitro activity of telithromycin against Haemophilus influenzae. Pathol Biol (Paris) 2002, 50:58-62.

28. Drago L, De Vecchi E, Nicola L, Colombo A, Gismondo MR: Selection of resistance of telithromycin against Haemophilus influenzae, Moraxella catarrhalis and streptococci in comparison with macrolides. J Antimicrob Chemother 2004, 54:542-545.

29. Sethi S, Anzueto A, Farrell DJ: Antibiotic activity of telithromycin and comparators against bacterial pathogens isolated from 3,043 patients with acute exacerbation of chronic bronchitis. Ann Clin Microbiol Antimicrob 2005, 4:5.

30. Brook I, Hausfeld JN: Effect of telitrhomycin and azithromycin on nasopharyngeal bacterial flora in patients with acute maxillary sinusitis. Arch Otolaryngol Head Neck Sur 2006, 1 32:442-445.

3I. Inoue M, Kaneko K, Akizawa K, Fujita S, Kaku M, Igari J, Yamaguchi K, Kohno S, Yamanaka K, linuma Y, Murase M, Yokoyama T, Asari S, Hirakata $Y$ : Antimicrobial susceptibility of respiratory tract pathogens in Japan during PROTEKT years I-3 (1999-2002). J Infect Chemother 2006, | 2:9-2I.

32. Pankuch GA, Lin G, Appelbaum PC: Activity of five quinolones, three macrolides and telithromycin against 12 Haemophilus influenzae strains with different resistance phenotypes. Clin Microbiol Infect 2005, I I: 1040-1044.

33. Drago L, De Vecchi E, Nicola L, Legnani D, Gismondo MR: Kinetic bactericidal activity of telithromycin, azithromycin and clarithromcyin against respiratory pathogens. APMIS 2005, I 1 3:655-63.

34. Craig WA: Re-evaluating current antibiotic therapy. Resp Med 200I:SI2-SI9.

35. Jacobs MR, Felmingham D, Appelbaum PC, Grüneberg RN, the Alexander Project Group: The Alexander Project 1998-2000: susceptibility of pathogens isolated from community-acquired respiratory tract infection to commonly used antimicrobia agents. J Antimicrob Chemother 2003, 52:229-246.

36. Tristram S, Jacobs MR, Appelbaum PC: Antimicrobial Resistance in Haemophilus influenzae. Clin Microbiol Rev 2007, 20:368-389.

\section{Publish with Biomed Central and every} scientist can read your work free of charge

"BioMed Central will be the most significant development for disseminating the results of biomedical research in our lifetime. "

Sir Paul Nurse, Cancer Research UK

Your research papers will be:

- available free of charge to the entire biomedical community

- peer reviewed and published immediately upon acceptance

- cited in PubMed and archived on PubMed Central

- yours - you keep the copyright
BioMedcentral 